\title{
A Rare Cause of Chest Pain: Acute Pericarditis Associated with Clozapine Treatment
}

\author{
Nadir bir Göğüs Ağrısı Nedeni: Klozapin Tedavisi ile Akut Perikardit Birlikteliği
}

\section{Tolga Sinan Güvenç, Șükrü Aksoy, Rengin Çetin, Baran Karataș, Erkan İlhan, Hatice Betül Erer, Mehmet Eren}

Siyami Ersek Gögüis Kalp ve Damar Cerrahisi Eğitim ve Arastırma Hastanesi, 6. Kardiyoloji Kliniği, Istanbul, Türkìve

\begin{abstract}
Clozapine is an atypical antipsychotic drug used in the treatment of schizophrenia. Cardio toxicity in therapeutic doses is an important concern for the safety of the drug, as there are reported cases of myocarditis, pericarditis and cardiomyopathy following clozapine use. Our aim is to report a rare, but important cause of chest pain in a schizophrenia patient. A 20 year-old male with schizophrenia and on clozapine treatment admitted to our hospital and he was diagnosed with acute pericarditis based on the clinical examination, electrocardiographic and echocardiographic findings. Discontinuation of clozapine resulted in remission of the signs and symptoms within 5 days. Although acute pericarditis is the rarest manifestation of clozapine cardio toxicity it is important in clinical practice. Failure to recognize may result with serious consequences, including pericardial tamponade and fulminant myocarditis.
\end{abstract}

Key words: clozapine, pericarditis, schizophrenia, pericardial effusion, chest pain

\section{ÖZET}

Klozapin, șizofreni tedavisinde kullanılan ve atipik antipsikotik özellikleri olan bir ilaçtır. Klozapinin terapötik dozlarda güvenli kullanımında kardiyotoksisite dikkate alınmalıdır çünkü klozapin kullanımı sonrası miyokardit, perikardit ve kardiyomiyopati olguları bildirilmiștir. Amacımız, bir șizofreni hastasındaki gögüs ağrısı șikayetinin nadir ama önemli sebebini bildirmektir. Șizofrenisi olan ve klozapin kullanan yirmi yașında, bir erkek hasta göğüs ağrısı nedeni ile hastanemize bașvurdu ve klinik, EKG ve ekokardiyografi bulgularına dayanılarak akut perikardit tanısı konuldu. Klozapin'nin kesilmesi sonrasında 5 gün içerisinde belirti ve bulgular geriledi. Akut perikardit, klozapinin en nadir kardiyotoksik yan etkisi olmakla beraber klinik olarak önemlidir. Klozapin kullanan hastalarda bu önemli yan etkinin fark edilmemesi, perikardiyal tamponad ve fulminant miyokarditi de içeren önemli sonuçlar doğurabilir.

Anahtar kelimeler: klozapin, perikardit, șizofreni, perikardiyal efüzyon, göğüs ağrısı

Tolga Sinan Güvenc, Dr. Siyami Ersek Hastanesi, Tibbiye Cad. No:25, Haydarpasa, Istanbul, Tel.02164445257Email.tsguveno@gmail.com Gelis Taribi: 28.04.2011 • Kabul Taribi: 13.05.2011
Chest pain caused by acute pericarditis is an important cause of emergency department admissions, particularly in young people. Albeit the most common etiologic factors for acute pericarditis are viral infections, a number of offending drugs are also known to cause this disorder. Clozapine is one of these drugs, which is an atypical antipsychotic drug used in the treatment of schizophrenia.

In this article, we describe a 20 year-old male patient who was diagnosed with paranoid schizophrenia and treated with clozapine for 3 days. He admitted to our emergency department with chest pain and subsequently was diagnosed with pericarditis. We discuss the pericarditis and subsequent myocarditis caused by clozepine, because it could be fatal, in contrast to benign and self-resolving nature of viral pericarditis.

\section{Case Report}

A 20 year-old male diagnosed with paranoid schizophrenia 15 days ago was referred to our emergency department from a psychiatry clinic following the onset of chest pain. Clozapine $50 \mathrm{mg} /$ day had been initiated 3 days ago. His medical and family histories were unremarkable. He did not have flu-like symptoms in the previous 15 days and he didn't use any medication other than clozapine.

On admission he had stabbing chest pain radiating to his left shoulder. His blood pressure, heart rate and body temperature were $130 / 70 \mathrm{mmHg}, 95$ beats/ minute, $38.5^{\circ} \mathrm{C}$, respectively. Physical examination revealed a pericardial rubbing sound at the left sternal border. 


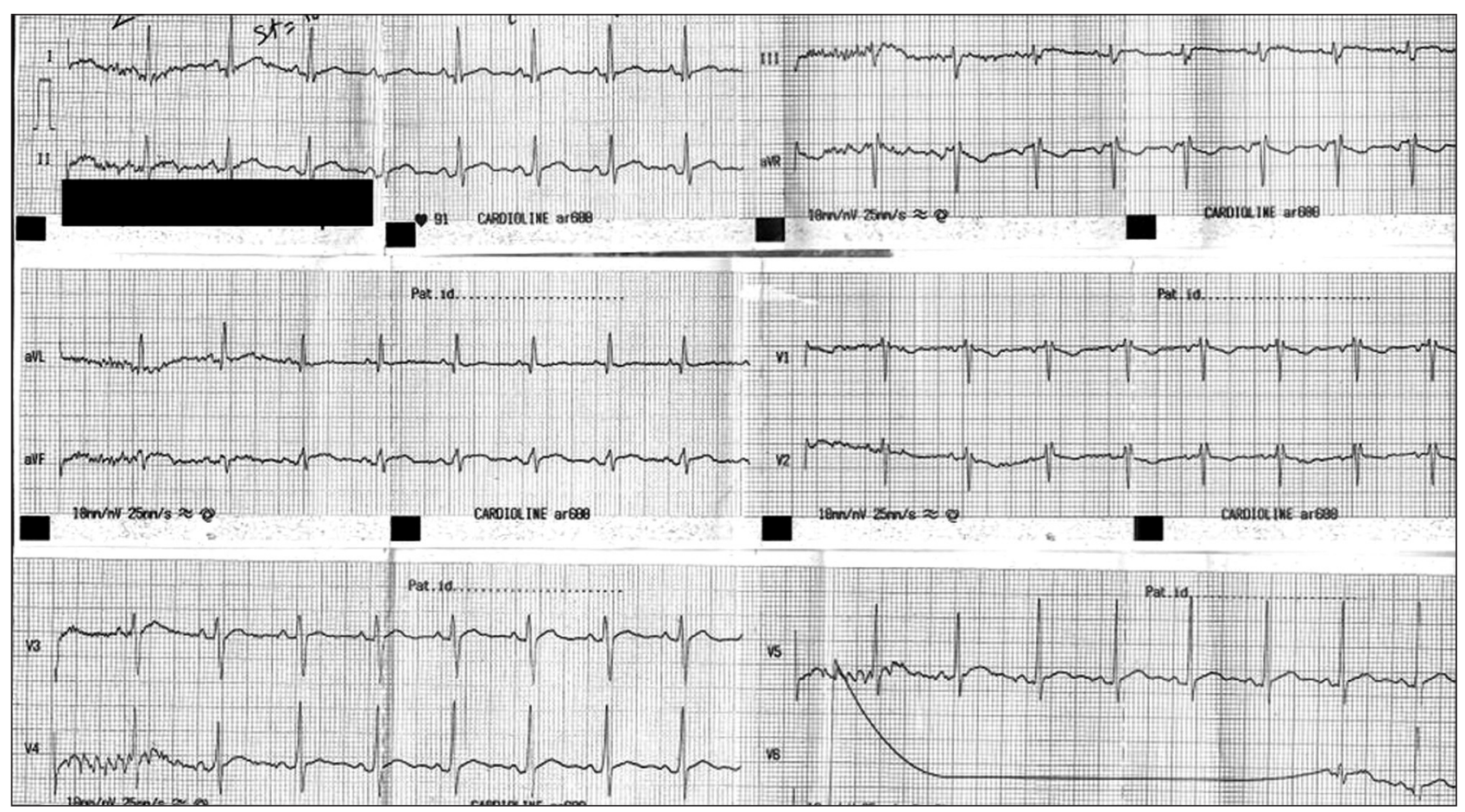

Figure 1. Electrocardiogram of the patient obtained at admission. ST-segment elevations were present in all leads except leads V1 and aVR, in which ST segment depressions were observed.

In the electrocardiographic (ECG) examination, ST-segment depressions of $1 \mathrm{mV}$ in leads V1 and aVR, and ST segment elevations in all other leads were observed (Figure 1). Plain chest X-ray was unremarkable. Complete blood count revealed a white blood cell count of $15.000 / \mathrm{mm}^{3}$ with a neutrophilic dominance. In biochemical analysis acute phase reactants were increased as: $\mathrm{C}$ reactive protein: $45.2 \mathrm{mg} / \mathrm{dl}$ and erythrocyte sedimentation rate:56 mm/h. Other biochemical parameters including renal and liver function tests, and cardiac biomarkers including Troponin I and NT-proBNP were unremarkable.

In order to have a more accurate diagnosis, we performed an echocardiographic examination (eSaote MyLab, Esaote S.p.A, Italy) and we observed some pericardial effusion adjacent to the infero-lateral wall of left ventricle and free wall of right ventricle (Figures 2 and 3). There was no significant wall motion abnormality.

As the patient's history didn't suggest a viral etiology, clozapine was identified as the offending agent and the drug was discontinued. On the third day of his admission, the symptoms and the signs remitted with a remarkable drop in acute phase reactants. In addition, there was a minimal pericardial effusion in the repeat echocardiographic examination. The patient was transferred back to his initial institution on the fifth day of his admission.

\section{Discussion}

Acute pericarditis is an important disease that should be considered in patients admitted to emergency department with chest pain ${ }^{1}$. The most important findings of this disorder include precordial chest pain of "pleuritic" quality that radiates towards trapezius ridge, neck, arms or jaw. Main oscultatory finding specific to pericarditis is a pericardial friction $\mathrm{rub}^{2}$.

In acute phase, ECG demonstrates a widespread ST segment elevation with PR segment depression on all leads except leads aVR and V1, in which the reverse is observed ${ }^{3}$.

Acute phase reactants such as leucocyte count, CRP and erythrocyte sedimentation rate are usually elevated. When associated with myocardial injury, troponin levels are elevated ${ }^{4}$.

Echocardiography is not needed for diagnosis, but should be performed when diagnosis is in doubt or 


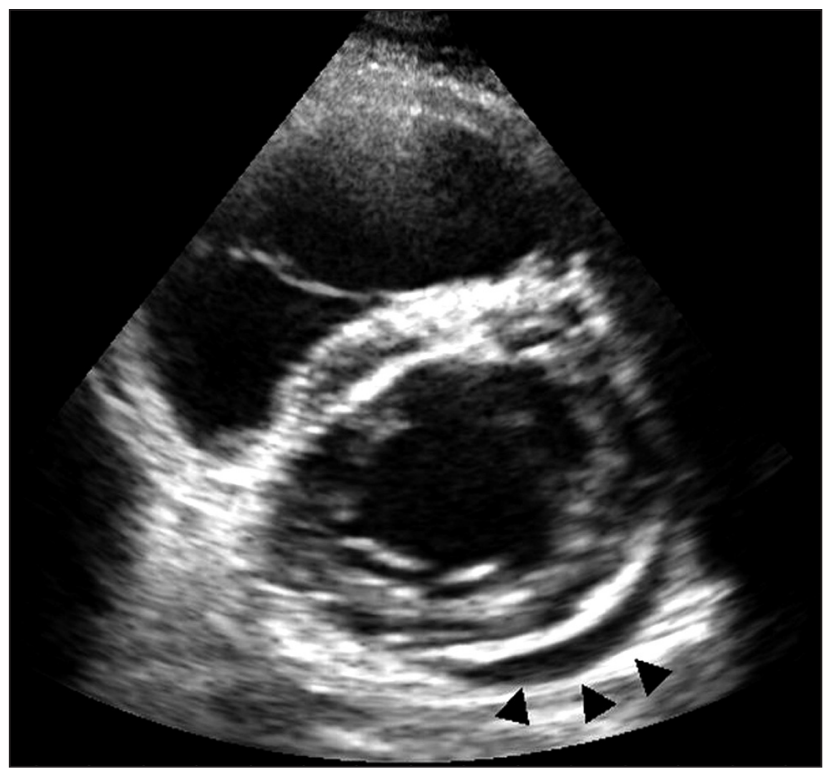

Figure 2. Transthoracic echocardiogram in parasternal short-axis view. Arrowheads show pericardial effusion present adjacent to left ventricular inferolateral wall.

tamponade is suspected ${ }^{5}$. In our patient, all these features were present with a typical clinical picture, so the diagnosis was established. The lack of elevation in troponin levels or wall motion abnormality on echocardiography ruled out myocarditis.

Clozapine is a tricyclic dibenzodiazepine derivative used in the treatment of schizophrenia. The main concerns about the safety profile of this drug focus on its toxic effects on cardiovascular system. Acute myocarditis is the most frequently reported cardiovascular side effect of this drug. Documented acute pericarditis is rarer, with only a few cases reported in literature. Pericarditis occurs soon after the institution of therapy and it may be a part of a generalized polyserositis syndrome, with pericardial, pleural and sometimes peritoneal fluid accumulation ${ }^{6,7}$. Unlike acute viral pericarditis which resolves spontaneously, clozapine-associated pericarditis tends not to resolve until the drug is discontinued ${ }^{8}$ and may relapse after reinstitution of the $\mathrm{drug}^{9}$. Cardiac tamponade requiring pericardiocentesis due to clozapine-associated pericarditis was also reported ${ }^{9,10}$. In our case, pericarditis occurred three days after the initiation of clozapine and was the only manifestation of cardiovascular toxicity. Accumulated fluid in pericardial space was inadequate to cause hemodynamic instability, and the cessation of the drug prevented further fluid accumulation.

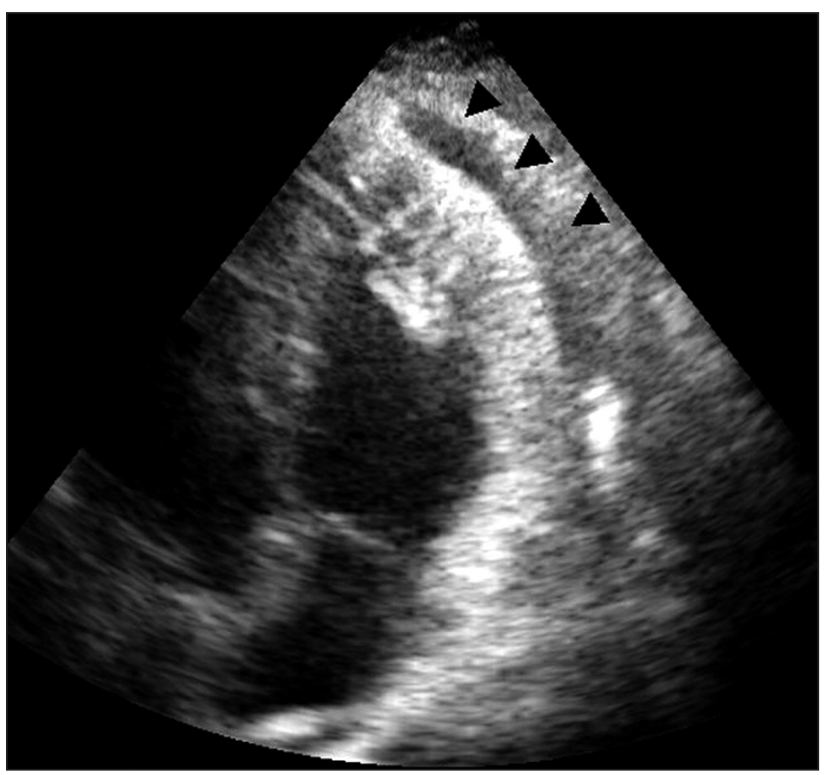

Figure 3. Transthoracic echocardiogram in modified apical 4-chamber view. Arrowheads show pericardial effusion present adjacent to right ventricular free wall.

The mainstay of therapy for all cardiovascular side effects is the withdrawal of clozapine. Pericardial effusions tend to resolve within one week following the discontinuation of clozapine, without any specific therapy ${ }^{8}$. This was also the case for our patient. Albeit only supportive measures were taken, pericardial fluid regressed spontaneously after drug withdrawal.

In conclusion, pericarditis is an important side-effect of clozapine therapy which must be diagnosed immediately. As failure to diagnose and delay in clozapine withdrawal may lead to pericardial tamponade and other potentially fatal complications.

\section{References}

1. Spodick DH. Differential diagnosis of acute pericarditis. Prog Cardiovasc Dis 1971; 14: 192-209.

2. Spodick DH. Pericardial rub. Prospective, multiple observer investigation of pericardial friction in 100 patients. Am J Cardiol 1975; 35: 357-62.

3. Aikat S, Ghaffari S. A review of pericardial diseases: clinical, ECG and hemodynamic features and management. Cleve Clin J Med 2000;67: 903-14.

4. Bonnefoy E, Godon P, Kirkorian G, et al. Serum cardiac troponin I and ST-segment elevation in patients with acute pericarditis. Eur Heart J 2000;21: 832-6. 
5. Maisch B, Seferovic PM, Ristic AD, et al., for the Task Force on the Diagnosis and Management of Pericardial Diseases of the European Society of Cardiology. Guidelines on the diagnosis and management of pericardial diseases executive summary. Eur Heart J 2004; 25: 587-610.

6. Daly JM, Goldberg RJ, Braman SS. Polyserositis associated with clozapine treatment (letter). Am J Psychiatry 1992; 149: 1274- 5.

7. Catalano G, Catalano MC, Frankel Wetter RL. Clozapine induced polyserositis. Clin Neuropharmacol 1997; 20: 352-6.

8. Raju P, Rao GK, Davis G. Pericardial effusion in patients with schizophrenia: are they on clozapine? Emerg Med J. 2008; 25: 383-4.

9. Murko A, Clarke S, Black DW. Clozapine and pericarditis with pericardial effusion. Am J Psychiatry. 2002; 159: 494.

10. Dauner DG, Deremer CE, Haburchak D. Clozapine-induced pericardial effusion. J Clin Psychopharmacol 2008; 28: 455-6. 